\title{
U-Pb chronology and geochemistry of detrital monazites from major North American rivers
}

\author{
KAZUMI YOSHIYA ${ }^{1 *}$, KeITA ITANO ${ }^{2}$, TSUYOSHI IIZUKA ${ }^{1}$, \\ SHIGENORI MARUYAMA ${ }^{3}$ \\ ${ }^{1}$ University of Tokyo \\ (*correspondence: k-yoshiya@eps.s.u-tokyo.ac.jp) \\ ${ }^{2}$ Kanazawa University \\ ${ }^{3}$ Earth-Life Science Institute, Tokyo Institute of Technology
}

The North American continent formed through collisions of Archean cratons which surrounded by Proterozoic orogenic belts, and the outermost parts are enclosed by Phanerozoic orogens. Detrital minerals in river sands have been eroded from basement rocks along rivers, and transported to the river mouth areas. Monazite, one of the robust minerals, is a light rare-earth element phosphate which can be precisely dated by the U-Th- $\mathrm{Pb}$ method. Monazite occurs as an igneous mineral in low-Ca peraluminous felsic rocks and as a metamorphic mineral in a wide range of metamorphic rocks. Previous monazite chronology and geochemistry revealed that detrital monazites from the African rivers recorded orogenic metamorphic events more accurately than detrital zircons [1].

To constrain the timing and nature of major orogenic events that formed the North American continent, we analyzed U-Pb ages and geochemical compositions of 178 detrital monazite grains from the Mississippi and Mackenzie Rivers. The U-Pb age distribution of detrital monazite from the Mackenzie River shows four large peaks at 0.15-0.2, 1.81.9, 2.0, 2.6 Ga and small peaks at 0.45 and $2.5 \mathrm{Ga}$. And that from the Mississippi River shows three large peaks at 1.45 , 1.7, 2.65 Ga and small peaks at 0.4, 1.1, 1.65, 1.85 Ga. By comparing with previously obtained detrital zircon $\mathrm{U}-\mathrm{Pb}$ age peaks $[2,3,4]$, large peaks are quite different from them. Comparison with geological events, $0.15-0.2$ Ga peak of the Mackenzie River reflect contributions from the Cordilleran orogen [5]. Other large peaks around 1.8-2.0 Ga may reflect contributions from the Thelon, Wopmay and Trans-Hudson orogens. The largest peak of monazite from the Mississippi River observed around $1.4 \mathrm{Ga}$. It may reflect contributions from anorogenic magmatism [6] or early stage of the Grenville Orogen [7].

[1] Itano et al. (2016), Precam. Res. 282, 139-0156. [2] lizuka et al. (2005), Geology 33, 485-488. [3] Rino et al. (2004) Phys. Earth Planet. Inter 146, 369-394. [4] Rino et al. (2008) Gondwana Res. 14, 51-72. [5] Gehrels et al. (2002) EPSL 199, 201-210. [6] Nyman et al. (1994) Geology 22, 901-904. [7] Windley (1993) J. Geol. Soc. 150, 39-50. 